\title{
NOTES ON THE GEOLOGY AND GEOMORPHOLOGY OF DE WITT ISLAND, SOUTHWEST TASMANIA
}

\author{
by Grant Dixon and lan Houshold
}

(with two text-figures and four plates)

Dixon, G. \& Houshold, I., 1996 (30:vi): Notes on the geology and geomorphology of De Witt Island, southwest Tasmania. Pap. Proc.

R. Soc. Tasm. 130(1): 67-73. https://doi.org/10.26749/rstpp.130.1.67 Parks and Wildlife Service, GPO Box 44A, Hobart,

Tasmania, Australia 7001.

De Witt Island, off the south coast of Tasmania, is composed of a folded succession of turbiditic silstone, sandstone and conglomerate, at least $450 \mathrm{~m}$ thick. It is probably a correlate of the Mid to Upper Cambrian Ironbound Group. Folds are upright, open to tight, and at least two generations are indicated. The broad-scale geomorphology of the island is controlled by the direction of storm waves which have eroded nearly vertical cliffs up to $340 \mathrm{~m}$ high on the south shore. Many sea caves are found at the base of the cliffs, particularly on the west and sourh coasts. Cliff retreat has progressively captured the headwaters of the island's two perennial streams. Fluvial processes, controlled by both lithology and structure, but also showing possible influence from interglacial and glacial stages, have shaped the interior of the island for a long period. Aeolian processes have deposited sand sheets in the island's central basin. Some well-developed pseudokarst systems, including sinkholes, caves, underground drainage and airflows, are related to large rotational slumps on the island's south coast. Key Words: Cambrian sediments, turbidites, coastal stream capture, mass movement, pseudokarst, Tasmania.

\section{INTRODUCTION}

De Witt Island is the largest of the Maatsuyker Group of islands, all of which are part of the Tasmanian Wilderness World Heritage Area. It lies some $6 \mathrm{~km}$ south of Louisa Bay, on Tasmania's south coast. The island is broadly triangular in shape, some $3 \mathrm{~km}$ across and $6 \mathrm{~km}^{2}$ in area, with cliffs (250-300 m high to the south) on all sides except a part of the central north coast. The highest parts of the island are located very close to the south coast, and enclose a northfacing basin. The island's $340 \mathrm{~m}$ summit is located very close to its southermost point.

The island is almost completely forested. Rainforest occurs in the major creek valleys, open mixed forest occurs throughout the north-facing basin, and dense tea-tree forest and wind-pruned coastal scrub occur in the northwest and far west of the island. Tussock and associated vegetation occurs on several very steep coastal slopes in the northwest. Dense, tall bracken fern blankets an area around the small northern estuary, an area which has been repeatedly burnt in the past (White 1981). However, the large size of many of the eucalypts, presence of rainforest vegetation and lack of evidence of charcoal attest to a long period without fire for the eastern half of the island.

Forest soils in the unburnt part of the island are deep, brown and peaty, with a thick litter layer in most areas. The burrowing activities of various seabirds have significantly affected soil development in several areas, particularly around the estuary and on steep slopes in the east, south and northwest.

Bedrock outcrop is generally poor in the island interior. However, exposure is excellent and near-continuous around the coast, although very steep slopes and thick coastal vegetation restrict access. No earth scientist has previously made on-ground observations on De Witt Island.

\section{Previous Geological Observations}

Lord (1928) noted white conglomerate or quartzite on Baldy Point, the northeastern tip of De Witt Island. White (1981) reported schist and shale from the west coast and micaceous sandstone from the north coast. The 1:250,000 geological map compiled for the region (Williams \& Corbett 1977) shows De Witt Island as undifferentiated Precambrian metamorphic rocks.

Banks (1993) summarised the available geological observations of De Witt Island and described two rock samples, a siliceous conglomerate and a thinly bedded quartzite, collected by Nigel Brothers. He concluded that the De Witt Island rocks most closely matched the "Younger Precambrian" (Spry \& Baker 1965) rocks at Bathurst Channel, but that there was some similarity with parts of the sequence on the Ironbound Range.

The western islands of the Matsuyker Group (Maatsuyker, Walker and Flat Witch Islands, Needle Rocks) are composed of polydeformed Precambrian rocks, mainly schists (Banks 1993), but the thick bedding visible in the southern cliffs of De Witt Island, and also in Flat Top and Round Top Islands, indicate that these islands are distinctly different.

\section{BEDROCK GEOLOGY}

Three associations have been identified on De Witt Island - a massive siliceousconglomerate, a conglomerate-siltstone association and a micaceous siltstone. A geological map of De Witt Island is shown in figure 1.

\section{Massive Conglomerate}

Massive conglomerate occurs as thick, subvercically dipping units in the northeast of De Witt Island, outcropping conspicuously as a broad rib and bluff above Baldy Point. 


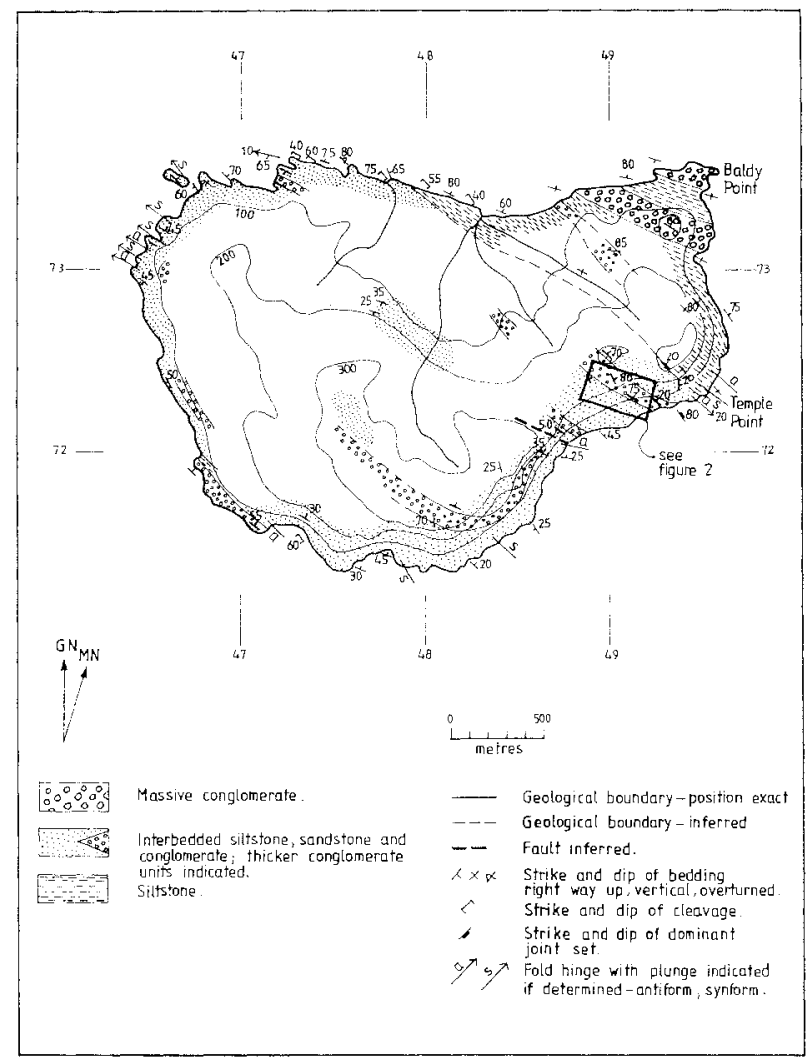

FIG. I - Geological map of De Witt Island. The geomorphological map (fig. 2, see p. 72) encompasses the area indicated by the box.

The rock is a generally coarse, white, siliceous conglomerate. It is clast-supported, consisting mostly of subrounded clasts of quartzite and quartz schist, the latter tending to be the more angular. Most of the clasts are somewhat elongated $(\mathrm{a}: \mathrm{c}=1.5-3)$ and range in size from $10-80 \mathrm{~mm}$ maximum dimension. Rare larger $(0.15-0.20 \mathrm{~m})$ subangular quartz schist clasts occur. The matrix consists of sand and fine pebbles. Separate beds are not discernible at outcrop scale, but a clear imbrication is apparent.

This unit is considered here separately from the conglomerate units within the finer grained succession, discussed below, on account of its more massive nature, larger modal clast size and clear imbrication.

\section{Interbedded Siltstone and Conglomerate}

An interbedded succession of siltstone, pebbly siltstone or sandstone and conglomerate comprises most of island (pl. 1). However, within the interbedded succession, extensive parts tend to be dominated by a particular lithology. In particular, there are sections in which conglomerate comprises a stratigraphically significant part of the succession (fig. 1). Conglomerate also occurs as isolated beds within finer grained parts of the succession. In broad terms, siltstonesandstone and fine sandstone-conglomerate associations are apparent and may be able to be separated with more detailed mapping.

The siltstone is grey (rarely greenish) and laminated or thinly bedded, generally $<5 \mathrm{~mm}$ thick. Quartzitic pebble beds or lenses, up to $0.1 \mathrm{~m}$ thick but usually much less, occur sporadically, and rare subrounded quartzite clasrs

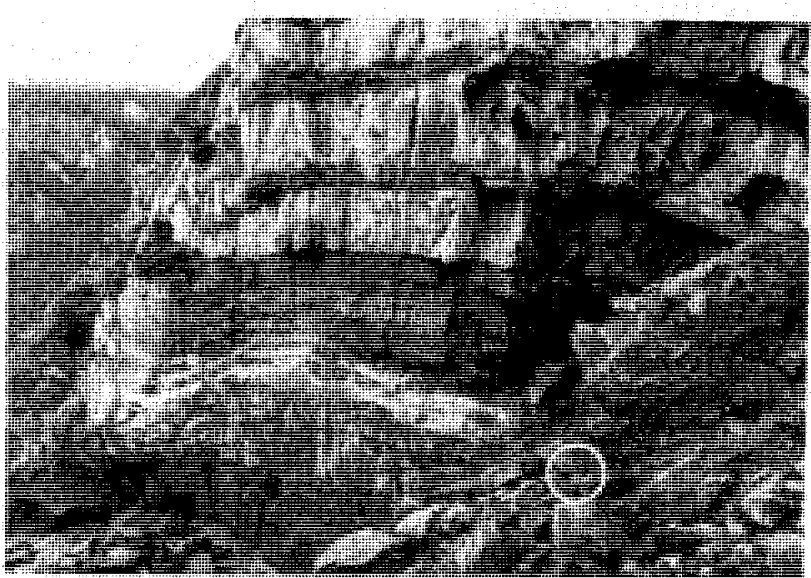

PLATE I

Interbedded conglomerate (light coloured) and quartz siltstone (dark) east of Temple Point. The entrance to a relict sea cave, some $30 \mathrm{~m}$ long and $5 \mathrm{~m}$ above present sea level, lies behind the debris fan at right. Note person (circled) for scale, bottom right.

$30-40 \mathrm{~mm}$ in diameter have also been noted. Sandstone beds are dark grey, quartz-rich and can be somewhat indurated. The lower few centimetres of sandstone beds, parricularly where they overlie conglomerate, tend to be pebbly - perhaps a poorly developed basal grading. At DM478735, several beds of greenish pebbly siltstone are interbedded with grey siltstone, with beds $0.2-0.5 \mathrm{~m}$ thick. Pebbles are quartzitic, rarely feldspathic and subangular. Further west, near DM474736,0.3 m thick graded pebbly sandstone beds or lenses are interbedded or intercalated with siltstone which contains rarc subrounded quartzite pebbles. Pebble contenc of beds varies laterally in many places.

The conglomerate units are white and siliceous, with clasts consisting of quartzite, quartz and rare quartz schisc. The rock is generally matrix-supported but is clast-supported locally. The clasts are subrounded to subangular, $5-40 \mathrm{~mm}$ maximum dimension (modal size varies at different localities) and elongate $(a: c=2)$. Cobble-size clasts occur locally or in some beds, and in these areas the conglomerate tends to be clast-supported (e.g. west of Temple Point and at DM489724). The conglomerate comprises massive beds, rarely displaying internal lamination or imbrication, but is sometimes size graded (co pebbly sandstone at DM493725) from 0.5 to more than $5 \mathrm{~m}$ thick. At DM474736, a $1.5 \mathrm{~m}$ thick graded conglomerate unit lenses out along strike within $10 \mathrm{~m}$.

The succession in the northwestern part of De Witt Island contains less conglomerate, consisting mainly of interbedded grey silestone and dark micaceous sandstone with rare pebbly (quartzwacke?) horizons.

Load casts are apparent where silty or sandy beds underlie some conglomerate horizons, well exposed at DM493723. In the same area, a coarse siltstone bed displays upwardly disrupted laminae suggestive of fluid escape. These structures are regularly spaced, with a $0.4 \mathrm{~m}$ separation, throughout the $25 \mathrm{~m}$ long exposure of this bed.

A succession some $450 \mathrm{~m}$ thick is exposed in the southern cliffs, below the island's summit, where about $200 \mathrm{~m}$ of predominantly sandstone-siltstone is overlain by pebbly sandscone or conglomeratic units. 


\section{Siltstone}

This unit is exposed as a very steeply dipping succession along much of the north coast of De Witt Island, particularly around the small estuary and main landing place. Whilst described here as a distinct rock unit, it is likely that the siltstone is merely a more consistently pelitic part of the previously described unit, with no conglomerate lenses or beds noted.

The rock consists of micaceous siltstone and sandstone, with rare granule sandstone. Many beds are finely laminated (1-3 $\mathrm{mm}$ thick), with wavy lamination common, and truncated cross lamination developed in some sandier beds. Partial Bouma sequences (ACD, ABCD, BCD), 0.20 $0.25 \mathrm{~m}$ thick, can be discerned in several areas. Convolute laminae and "dish" or fluid escape structures occur in several discrete siltsrone beds.

Closures exposed in the eastern cliffs indicate that the siltstone unit has been tighrly folded, at least in parr. The unit may therefore be as litrle as $200 \mathrm{~m}$ thick, with parts of the succession exposed along the north coast repeated.

\section{Age and Geological Relationship}

Given the geographical proximity, the rocks of De Witt Island can be correlated with the Ironbound Group (Findlay 1994) on lithological grounds. The massive conglomerate is similar to the upper part of the Havelock Bluff Formation, and the interbedded siltstone, sandstone and conglomerate sequence has affinities with the Lousy Bay Formation. The rocks of Flat Top and Round Top Islands, which have been both observed by one of the authors (GD) and described by Banks (1993), are similar to those described herein and are likely also to be correlates of the Ironbound Group.

The Ironbound Group unconformably overlies polydeformed Precambrian rocks (which also occur on Maatsuyker and orher islands southwest of De Wirt Island). It is conformably overlain by Denison Group siliciclastics and is considered to be Mid to Late Cambrian in age (Findlay 1994).

No fossils were found in any of the rock unirs on De Witt Island. However, at DM478728, a single rounded feldspar porphyry clast, some $0.25 \mathrm{~m}$ in diameter, occurs in laminated quartzitic siltstone. The clast, comprising altered feldspar and lesser quartz in a fine, greenish groundmass, is similar to Cambrian volcanic units now exposed in western Tasmania. Findlay (1994) observed presumed Cambrian volcanic material in rocks of the Ironbound Group and noted that this supported a Mid to Late Cambrian age for the Group. A similar conclusion is indicated for the De Witt Island succession.

\section{Environment of Deposition}

Findlay (1994) considered the Ironbound Group to be a proximal fan sequence. The lithologies and range of sedimentary structures which occur in De Witt Island indicate rapid deposition, largely from turbidicy currents and debris flows, with occasional fluidised flow. Conglomerate lenses which occur within the sandstonesiltstone succession probably represent debris flows within channels. This incerpretation is consistent with the De Witt Island rocks comprising pare of the Ironbound Group.
Siltstone exposed on the north coast of De Witt Island may be a more distal parc of the sequence, compared with the sandstone-siltstone-conglomerate succession which comprises the southern parts of the island. This would suggest transport from the sourh or southwest, consistent with palaeocurrent directions inferred from observations of cross laminations exposed on the north coast, and also with Findlay's (1994) observations on the Ironbound Group in the Ironbound Range area.

\section{Geological Structure}

The De Witt Island succession has been folded, with a zone of relatively tight folds bisecting the island east-west, with very open folding occurring further to the south and very steep dips (but no apparent closures) to the north. This structural variation may relate partly to lithological differences, with the southern part of the island composed of predominantly coarser grained units. However, at DM474736, on the north coast, tight folding in sandstone and siltstone gives way abruptly to consistently steep dips to the north with no apparent discontinuiry or local lithological change.

Folds are generally upright to gently inclined and gently plunging, with axes trending east-west to northwestsoutheast. Fold style ranges from open to righe, almost isoclinal locally, with no significant differences in axial plane orientations. These differences appear to relate mainly to lithological variations, with open, parallel folds typical where coarser grained and conglomeratic units occur, tight similar folds observed in the finer grained and pelitic units, and chevron-style folds evident in part of the turbidite succession exposed on the west coast. Similarly, fold wavelengths range from $2-3 \mathrm{~m}$ to almost $50 \mathrm{~m}$ over a distance of $200-300 \mathrm{~m}$ along the northwest coast, the larger scale folds occurring in coarser lithologies. This lichological control on fold scyle and scale can result in distinctly disharmonic folding, as in the excellent coastal exposure at Temple Point, where open folding in thick conglomerate beds gives way to very tight, upright folding

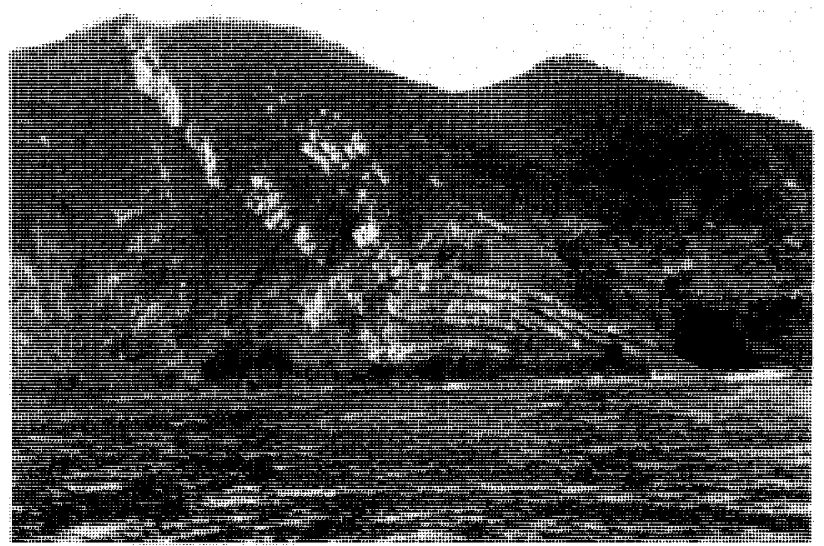

PLATE 2

Folding in conglomerate and siltstone on southeast coast, with very steep dips in siltstone at left, very open concentric folds in interbedded conglomerate-siltstone to right. The light-coloured ribs are siliceous conglomerate strike ridges. The major pseudokarst area occurs on the platean at top left and terminates, to the east, against the conglomerate strike ridge and pinnacle. 
in pelitic beds without apparent faulting or discontinuity (pl. 2). Folds in the west of the island plunge gently westwards, whereas those in the east plunge to the east or southeast. Later gentle warping of the island succession along a north-south axis is therefore indicated.

A structural foliation, which can be seen to be axial planar to folding near DM474736, occurs but is well developed only in the pelitic units exposed along the north coast. Here, the foliation dips moderately to steeply southwest, intersecting bedding at a high angle, thus giving rise to the jagged, sharp nature of coastal outcrops and controlling their alveolar surface weathering. Banks (1993) noted the development of muscovite flakes with two orientations, differing by $50^{\circ}$, in a "quartzite" sample obtained from the north coast. It seems likely that these orientations relate to bedding and the aforementioned structural foliatios.

Thin, irregular quartz veins and segregations occur in several localities, usually at a high angle to both bedding and cleavage. They may indicate high strain or hinge zones, but their occurrence is not ubiquitous.

Jointing is not generally well developed but is apparent in some of the more massive conglomerate units. Near Temple Point, widely spaced $(0.5 \mathrm{~m})$ subvertical joints are apparent in thick conglomerate beds, but joints are closely spaced and poorly developed in the thin sandstone and siltstone interbeds. Here also, the surface of a conglomerate dip slope shore platform is spectacularly dissected, grikelike (although the rock is not calcareous) along the joint sets.

\section{GEOMORPHOLOGY AND CAINOZOIC DEPOSITS}

The landforms of De Witt Island are controlled, on the broadest scale, by a combination of lithology and rock structure, geomorphic processes and inheritance of previous landforms. Whilst the fluvial pattern of the island and internal slope angles and orientations are strongly (though not completely) influenced by differential erosion of strata of varying resistance and by the presence of zones of structural weakness, the overall shape of the island, the orientation of its cliffs and nature of its coastal deposits result from the overriding of geological controls by powerful coastal processes. These are, in turn, controlled by climatic patterns influencing average storm wave directions.

In some instances, both geological and contemporary geomorphic controls on landforms are overridden by inheritance of patterns established during different climatic or eustatic conditions, which operated earlier in the Cainozoic. For example, at times of glacial low sea levels, the regional base level of erosion would have been well below the present ocean floor in the vicinity of the island (Banks 1993), and all marine processes surrounding the island would have ceased. This would have left only fluvial (and periglacial?) processes operating on that part of the southern highlands which, during interglacials, became isolated by rising sea levels. It is argued later that the main stream pattern on the island is due more to inheritance than to structural control or present-day geomorphic processes.

Cainozoic deposits on the island result from many of the more usual geomorphic processes operating on oceanic islands. These include coastal, fluvial, aeolian, mass movement and weathering lag deposits. More unusual deposits are chemical sediments deposited in sea caves as a result of solutional processes. No dating of the deposits was undertaken, but some scope exists for dating and palaeogeographical analysis of relict aeolian features, raised beach deposits and speleothems.

\section{Coastal Deposits and Geomorphology}

The most widespread Cainozoic deposits on the island are coastal deposits consisting predominantly of cliff-foot talus derived from erosion by storm waves. Most are active at present. These large angular deposits are found mainly on the exposed south and west coasts and are derived predominantly from collapse after erosion at the bases of cliffs. The prevailing southerly and westerly direction of storm waves is, at present, by far the most important control on the gross morphology of the island, being more influential than geological controls or inherited features.

It is likely that, during glacial low sea levels, the part of the southern highlands which is now De Witt Island would have attained a more rounded profile than at present, as only fluvial and, possibly, periglacial processes (indicated by fossil slope deposits consisting of predominantly angular clasts at DM 470734) would have been operating. However, during the marine transgressions, and particularly the most recent, the enormous erosive capacity of the Southern Ocean has led to the undercutting of that rounded topography to produce a markedly asymetrical profile, with near vertical $300 \mathrm{~m}$ high cliffs facing the predominant southerly swells.

This continual undercutting and destabilisation have initiated mass movements of the upper cliff sections in three main ways. Firstly, massive rotational slumps are common on the south coast, on the well-vegetated cliff tops to the west of Temple Point. Although no recent scars are visible, it is likely that these slumps have contributed some of the more massive boulders to the cliff-foot deposits. These large slump areas are associated with some interesting pseudokarst features described below.

Secondly, and more commonly visible today, smaller individual landslides, consisting of boulders up to $1 \mathrm{~m}$ in diameter, are initiated from vegetated mid-cliff sources, probably greatly aided by waterlogging and other fluvial processes following heavy rains. Evidence of at least three major, recent landslides is found on the south coast, involving vertical disturbance of over $200 \mathrm{~m}$. It is likely that these landslips are reworking older, angular slope deposits originally emplaced during glacial stages. Although obscured by dense vegetation on the southern cliffs, fossil slope deposits containing predominantly angular clasts may be seen from the sea on the northwest coast, where wind pruning has prevented dense vegetation from establishing.

On the west coast, the third major style of breakdown is illustrated. The cliffs here are, in contrast to those on the southeast coast, predominantly unvegetated and almost perpendicular, but are not nearly as high. Breakdown appears to occur through a process of mass failure of entire faces rather than slumping or discrete landslips.

Although relatively small cliffs occur on the very northwest and northeast shores, the majority of the north coast consists of steep slopes fashioned more by fluvial processes than through mass movement initiated by wave acrion. Where cliffs do exist, they are more common above sea cave entrances, where undercutting has progressed at a faster rate. 
Many reasonably extensive sea caves are found around the island, although weather conditions allowed only a few to be examined in derail. Both active and relicr caves are present, some being found up to 3-5 $\mathrm{m}$ above present sea level. Sea caves are most common on the island's northwest shore, where storm waves may most effectively exploit the northwest-southeast orientation of the bedding and structure. All of the sea caves are essentially structurally controlled, although in many cases collapse has significantly modified the primary form. Many caves are found in fold hinges, in areas of relatively more erodible rocks and subvertical dips, with roofs and walls composed of more competent units.

Most sea caves contain well-rounded boulder deposits, although in many of the caves examined they were covered by extensive areas of roof collapse. Less collapse is evident in the caves of the sheltered north coast; the large cave at DM487733 possesses an almost complete primary form, with a floor composed entirely of rounded cobbles. One cave examined to the west of Temple Point contained sparse but reasonably massive ferruginous stalactices, as well as a large mass of coralloid speleothems on a conglomerate wall. Their composition has noc been determined.

Narrow shore platforms are present on the north shore, although the harder lithologies, in general, remain as steep ridges dividing planed areas of softer rock. Some interesting

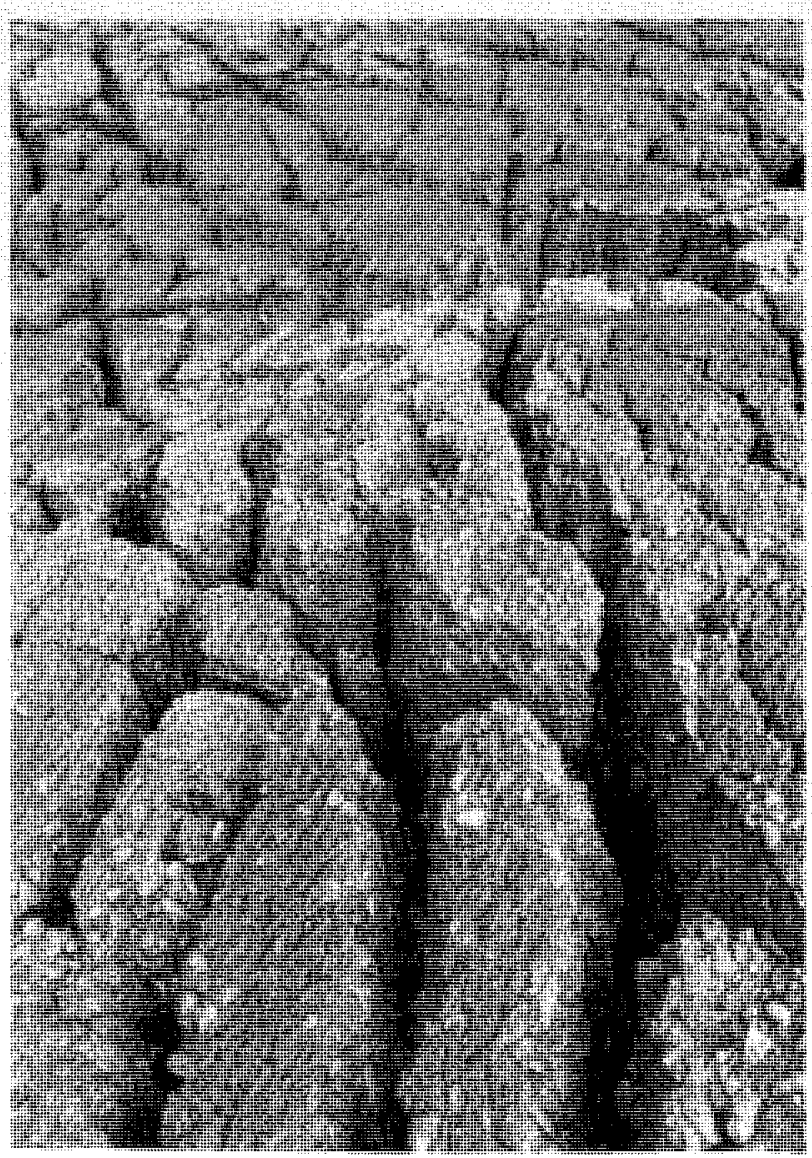

PLATE 3

Wave-excavated joint fissures in conglomerate, exposed in shore platform at grid reference 494724 . The width of the field of view, at base of photo, is approximately one metre. erosional micro-features are present on these surface,s including large, knife-edged erosional rem nants, where thin beds of hard strata are left following erosion of surrounding weaker beds, and dendritic channels, which have been deeply cut by ocean swells in well-jointed conglomerate (pl. 3).

Small, active boulder beaches are most common at the mouths of sea caves on the north shore and at the heads of more sheltered gutters. An apparently fossil cobble beach deposit is found at DM476736. This deposit appears to be approximately $2 \mathrm{~m}$ above an active beach and consists of clasts of rounded to subrounded, locally derived rocks in a clayey matrix.

Although the sea bed to the north of the island is essentially sandy, nowhere are the submerged shelfs shallow enough to allow the buildup of sandy beaches. Small sand pockets are found at the mouths of the island's main stream systems at DM 483733 and DM 478737.

\section{Aeolian Processes and Deposits}

Aeolian fearures are common along the north coast. It is assumed that aeolian features on the other, more exposed coasts are soon obliterated by more powerful coastal processes. To some extent, wind appears to be contributing to the erosion of weathered material and unconsolidated deposits along the sparsely vegetated northwest shore. Strong, salt laden winds have prevented the development of more than a sparse vegetation cover, which here consists of stunted hearhland and, on the steeper slopes, of a discontinuous cover of tussock grasses. Much wearhered siltstone is removed by wind, and alveolar weathering has resulted from sale crystallisation on exposed, soft rock faces below overhangs, where runoff is not present.

Large sand deposits are a feature of the north-facing basin. They do not form dunes, consisting more of sand sheets overlying fluvially eroded and weathered siltstones. These are now fossil features generally well consolidated by thick growths of bracken fern. They are exploited by Fairy penguins and Short-tailed shearwaters as burrowing sites. This activity incorporates a large a mount of fern breakdown in the sand, producing deep organic A horizons in the soil profile. It is possible that this extensive burrowing activity may have reduced any primary dune forms to the more continuous surface present today. It is likely that these deposits were emplaced during Late Pleistocene-carly Holocene times, when banks of sand to the north of the island were mobilised and exposed by fluctuating sea levels. Similar sand sheets and bioturbation effects on soil physics and chemistry are described by Pemberton (1991) from nearby Maatsuyker Island.

\section{Fluvial Landforms and Deposits}

De Witt Island is the only one of the south coast islands to possess perennial streams. Two main stream systems are found there, although each contributes only a few tens of litres/sec discharge even at peak flow. The water is particularly deeply stained by organic complexes, derived from longunburned forest peat soils and as a result of drainage from extensive rookeries of seabirds, which are continually incorporating organic materials inco quickly draining sandy soils by burrowing activities. 


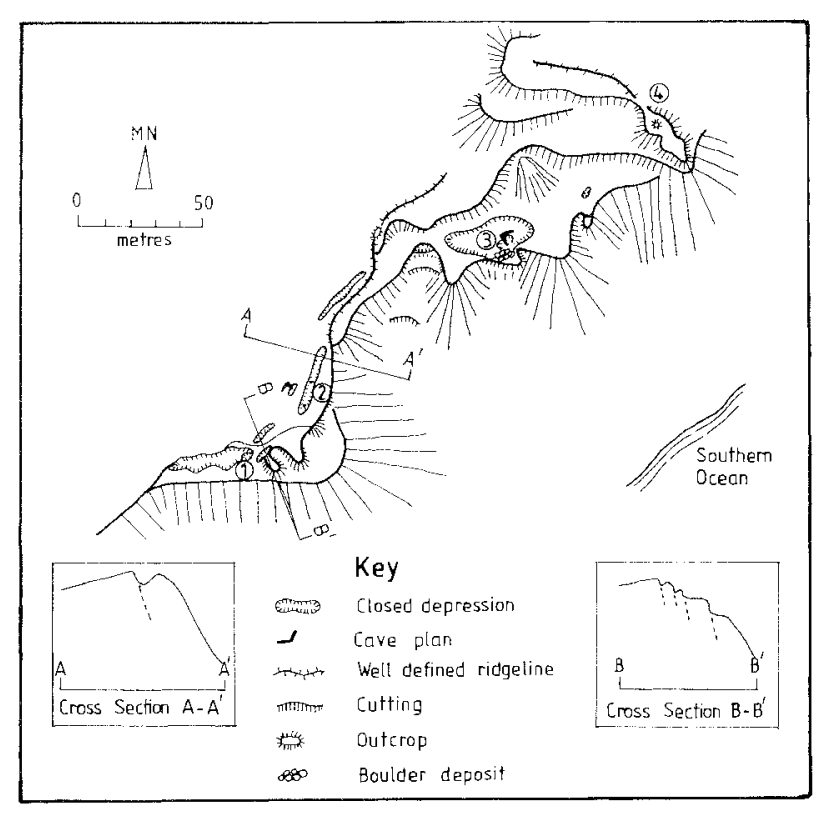

FIG. 2 - Geomorphological map of pseudokarst area, located at grid reference 489726; 1 to 5 refer to sites described in the text.

The main drainage system forms a fan-shaped basin on the island's eastern half. The largest stream roughly bisects the island. In its upper reaches, its course is structurally controlled, running parallel to the strike of the bedding and exploiting the axis of a synclinal structure. A third of the way down, it departs this trend to flow perpendicular to the strike over a series of cascades and small waterfalls, following no obvious structural control (no major joints or cleavage appear to run in this NNE direction). It is likely that here some form of landform inheritance plays a role in directing the stream's course, possibly related to stream capture, following lowering of regional base levels during one of the Pleistocene glacials. This orientation is mirrored by the other drainage system located further west on the island; its direction is probably controlled by similar circumstances.

The two tributaries of the main drainage system exhibit classical structural control, exploiting zones of comparatively soft siltstone between emergent conglomerate ridges, flowing parallel to the strike and joining the main stream near its mouth on the coast.

The drainage system shows remarkable evidence of being rapidly truncated at the headwaters, due to the encroachment of coastal cliffs from the south - a most extreme form of stream capture. At present, the drainage divide for most of the sourheastern part of the island is, in facr, the clifftop. A series of ridges and cols along the skyline marks the locations of former valleys and interfluves which no longer carry drainage, as the cliff is more rapidly undermined by coastal processes than fluvial systems can initiate southerly flowing stream systems. Each minor ridge appears to be controlled by the presence of coarser grained rocks (conglomerate or pebbly units in the sandstone or siltstone units), whilst the cols are generally in softer siltstone.

Before debouching to the sea, the streams converge to a point on the central north coast where a wide band of comparatively soft siltstone is found. The central basin is focussed on this soft rock; its contact with harder sandstones and conglomerates marks a considerable lessening of stream gradient. Small alluvial deposits are found along the margins of streams where they enter the basin, but most alluvial material appears to have been covered by the aeolian sand sheers.

The mouth of the stream consists of a small tidal inlet, which appears to be a very small example of a drowned valley cut during glacial low sea levels. Soundings at the mouth of this inlet indicate the valley continues northwards below present sea level.

Although exposure is poor, there appear to be very few significant angular slope deposits in the interior of the island. There are, however, large amounts of lag material, generally subrounded clasts derived from conglomerates, present on the slopes and broad ridge crests. Soils appear to be quite thick, especially on valley slopes and bottoms, and contain a large proportion of organic matter. This suggests that chemical weathering and fluvial processes have played the major role in denudation of the interior of the island, away from the influence of coastal processes.

\section{Pseudokarst}

Figure 2 illustrates an area to the west of Temple Point, where an unusual suite of mass movement and pseudokarst features is found. This is the better developed of two such sites on the island, consisting of closed and partly closed depressions, fissure caves and boulder caves, subsidence terraces and large rotational slump features. The other site, at DM 484719, contains closed depressions and subsidence rerraces also related to large rotational slump blocks (pl. 4).

First impressions of this area suggested that it was, in fact, a true karst area and led to early speculations that there may be dolomite on the island. Large closed depressions, of similar size and form to truly karstic depressions, and cave entrances with significant air movement more closely resemble the outward form of true karst than those in similar pseudokarst areas more commonly asssociared with dolerite slump blocks (e.g. Sharples 1995)

The Temple Point site is found in a sandstone and conglomerate unit bounded to the northeast by a band of coarse siliceous conglomerate (fig. 1). The pseudokarst is located at an altitude of approximately $250 \mathrm{~m}$, in the head

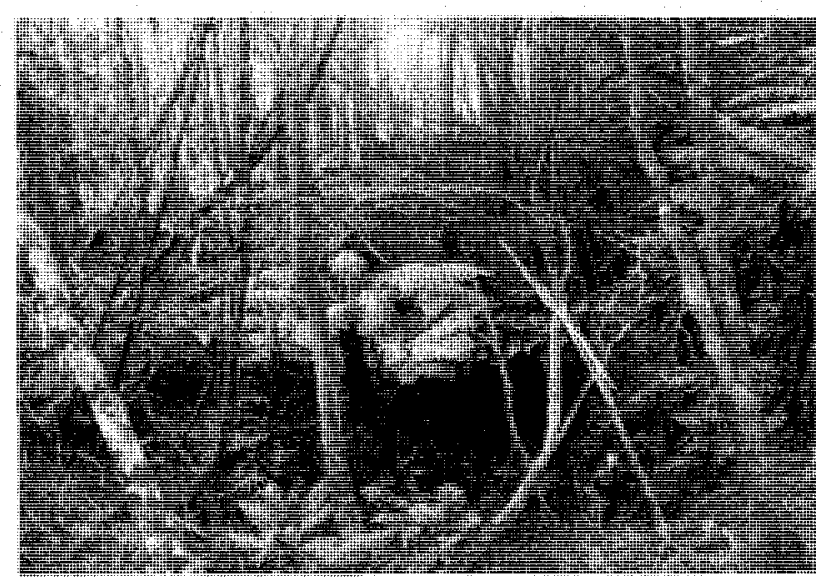

PLATE 4

Closed pseudokarst depression, about $10 \mathrm{~m}$ deep, at grid reference 484719. 
of a small, very steep valley. It appears that mass movements down this valley associated with minor fluvial erosion have destabilised an arcuate area at the valley head, initiating a series of rotational slumps whose axes are parallel to the cliffline at that point. Therefore, whilst the valley floor trends structurally in a northwest-southeast direction, rock structure has played only a minor role in determining the orientation of the individual slump blocks.

The direction of movement has been controlled more by the immediate relationship of the slump block has with the arcuate valley head; the partings between individual blocks and the main rock mass are likely to be controlled by a form of unloading joint more associated with the geomorphic history of the locality than with existing bedding, joints and cleavage planes.

The cross sections marked on figure 2 indicate the broad nature of the local topography. At B-B' four separate subsidence terraces are found, the upper two showing marked rotation, with the landward section of the terrace treads forming elongated closed depressions along the slip surfaces (site 1). At A-A', a major terrace containing two strongly draughting holes is backed by a single, slightly elongated closed depression with a cave of humanly enterable dimensions (site 2). This cave is penetrable to a depth of approximately $10 \mathrm{~m}$ and also issues a strong draught. The cave is developed in a wide fissure at the contact between the slump block and in situ bedrock. It contains many angular boulders, probably dislodged during the slumping process, which are partially infilled with a matrix of fine silt derived from surface wash. At its furthest point, the cave disperses into a boulder maze with no human access; however, the strong draught indicates the likelihood of a large air volume amongst breccia along the slump plane.

Site 3 is the best developed pseudokarst topography on the island, containing a $10 \mathrm{~m}$ deep, closed depression leading to a $15 \mathrm{~m}$ deep fissure cave. The cave shows evidence of fluvial modification of the collapse block walls and contains stratified sediments, indicating significant water flows from the internally draining catchment. It also issues a strong draught, but it too becomes impassable, due to boulder fills. The cave contains a dark zone with many invertebrate species, including cave crickets and at least three species of spiders. Hickmania troglodytes (Tasmanian cave spider) was not found anywhere on the island, but a smaller, though similar species also building a horizontal sheet web inhabits both caves. Also common is a species of woolly centipede, a life form not yet described from any Tasmanian cave ( $\mathrm{S}$. Eberhard, pers. comm.). Approximately $50 \mathrm{~m}$ northwest of site 3 , a $10 \mathrm{~m}$ long boulder cave is found passing through a short spur, an erosional remnant of a subsidence terrace.

Bounding the entire pseudokarst area to the northeast, a prominent strike ridge of competent, subvertically dipping conglomerate forms a major cliff leading almost vertically to sea level (Sire 4). No slump blocks have formed in this unit, and it appears that the entire pseudokarst area is backed onto it, the contact forming the limit of slump activity in this direction. A similar band approximately 200 $m$ to the southeast forms the boundary on that side.

\section{DISCUSSION}

The succession of folded clastic rocks occurring on De Witt Island, a probable correlate of the Ironbound Group (Findlay 1994), extends southwards the extent of Cambrian rocks in Tasmania. The continuous coastal exposures of these rocks, both in narrow shore platforms and high cliffs, are amongst the most spectacular in Tasmania. A proximal fan depositional environment is inferred for the succession; given this and the predominantly siliceous clast lithology, it is interesting to speculate on the source of the single cobblesize, rounded clast of?Cambrian volcanic porphyry noted in laminated quartz siltstone.

In broad terms, the geomorphology of the island very clearly illustrates a process of ongoing stream capture through the encroachment of coastal cliffs on the headwaters of a fluvial system. This style of stream capture and the attendant effects on surrounding landforms and processes are not well illustrated elsewhere in Tasmania. Whilst pseudokarst features are quite common below dolerite escarpments in eastern Tasmania and generally larger, the highly integrated nature of closed depressions, caves, fluvial and atmospheric processes make the De Witt Island examples amongst the best developed in the state.

\section{ACKNOWLEDGEMENTS}

Neil Smith, skipper of Wild Wind, is thanked for providing transport to and from De Witt Island. The caves on De Witt Island were first noted by Nigel Brothers, in 1986, and his descriptions provided the incentive for this investigation. Owen Barrett, lightkeeper on Maatsuyker Island, assisted with radio communications during our inclement weather confinement on the island. Carole Edwards is thanked for drafting the figures. GD completed this study whilst undertaking a project, Geoheritage Inventory of Tasmanian Islands, funded by the 1995/96 National Estate Grants Programme.

\section{REFERENCES}

BANKS, M.R., 1993: Reconnaissance geology and geomorphology of the major islands south of Tasmania. Rep. Dep. Parks, Wildl. Herit., Tasm.

Findlay, R.H., 1994: The Ironbound Group of Souchern Tasmania; new data bearing on the Cambro-Ordovician relationship between Tasmania and Northern Victoria Land, Antarcica. Miner. Resour. Tasm. Rep. 1994/14.

Lord, C., 1928: The South Coast and Port Davey, Pap. Proc. R. Soc. Tasm. (1927): 1-16.

Pemberton, M., 1991: The influence Short-tailed shearwaters have on soil development at Maatsuyker Island, south west Tasmania. Rep. Toyora Found.

ShARples C., 1995: A reconnaisance of landforms and geological sites of geoconservation significance in the state forests of eastern Tasmania, Rep. For. Tasm.

SPRY, A.H. \& BAKER, W.E., 1965: The Precambrian rocks of Tasmania, Part VII. Nores on the petrology of some rocks from the Port Davey - Bathurst Harbour area. Pap. Proc. R. Soc. Tasm. 99: 17-26.

WHITE, G., 1981: ISLANDS OF SOUTHWEST TASMANIA. The auchor, Sydney.

Williams, P.R. \& CoRbeTt, E.B., 1977: PORT DAVEY. Dep. Mines Geol. Atlas 1:250,000 Series, Sheet SK 55-7. 
